\title{
Dr. Rajendra Singh \\ His Tryst with Water and Peace
}

Dr. Rajendra Singh of Alwar in Rajasthan, the well known water conservationist, popularly known as Water Man of India, Bai Sahab in the households of Alwar, has been named as Swiss Water Prize Laureate for 2015 awarded by Stockholm International Water Institute in recognition of his "innovative water restoration efforts, improving water security in rural India, and for showing extraordinary courage and determination in his quest to improve the living

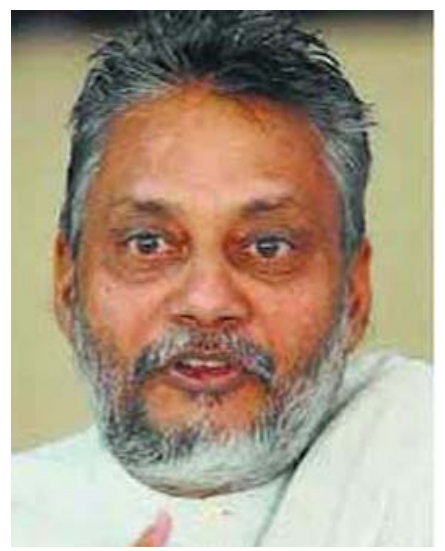

conditions for those most in need". The Swiss Award Committee further observes: "In a world where demand for freshwater is booming, where we will face severe water crisis within decades, if we do not learn how to better take care of our water, Mr. Singh is a beacon of hope.... He has literally brought villages back to life. We need to take Mr. Singh's lessons and actions to heart if we are to achieve sustainable water use in our lifetime".

Arwari, a nondescript river basin in Alwar district of Rajasthan, a desert land of dune sands has now sprung into the limelight of fame as a unique model of community driven watershed management and river rejuvenation. The Geological Society of India (GSI) proudly shares this moment of glory with the people of Alwar and the proud awardee, the humble Son of Mother India. It is his Tryst with Water and Peace for a Hunger-free World.

Way back in 1982, hailing from a village Daula in Bagpat district of Uttar Pradesh, after graduation in Ayurvedic Sciences, young Rajendra Singh took an employment in Nehru Yubak Kendra Sansthan as a National Volunteer, which gave him the opportunity of visiting Alwar villages in the desert heartland. He saw the plight of rural Rajasthan starved of food, drinking water and without sanitation. After a short stint in government service as Project Officer in Ministry of Education, the activist in him brought him over to Alwar in 1985 to launch a project for mitigation of water crisis, food and drinking water shortages under Tarun Bharat Sangh of Bhikampura, a Nongovernmental organisation of social workers and volunteers, which he instituted and nurtured as its mentor and leading activist. This was the beginning of a magnificent saga of Arwari river basin in the desert land.

Here Rajendra Singh launched his experiment with "Truth". It was a unique experiment in water cycle and management in the nature's laboratory of parched desert, pioneering indeed, which led to his 'enlightenment' of community driven integrated water management establishing the harmony of water, man and nature. This discovery now forms the foundation of watershed management, successfully tested in the villages of Arwari river basin in Alwar district of Western Rajasthan.

Reeling in droughts and monsoon failures, water crisis crippled all development and growth in the region, leaving the people in abject penury. Rivers were dry, wells and water bodies too dry or dilapidated. 
With critical shortage of water for drinking and farming, agriculture was abandoned, people migrated for alternative livelihoods. Illegal mining destroyed forests, river beds and water bodies. He was appalled to see the rigours of fetching water from kilometers away. Large tanks and johads or check dams, the most common and popular structures once used for harvesting water to successfully withstand few years of droughts, recharged the wells, and dotted the desert lands, were rendered derelict due to neglect with disastrous consequences on rivers and wells drying up. Whatever precipitation occurred was lost as flash floods. Hence he conceived of a mission for saving the forests and watersheds from the grip of unscrupulous mining, and harvesting rainwater by constructing johads, and renovating old ones, the traditional time tested systems of mudfilled, cost effective, simple structures for restoring Alwar's degraded habitat.

TBS mobilised the people through various stages of participatory approach adopting Gandhian principle of local autonomy and self-reliance. This led to the formation of gram sabhas, Mahila Sangathans, Youth Groups for collective discussions, decision making, designing, construction and management. Johads, the cornerstone of this movement were designed indigenously based on intuitive knowledge of villagers with the costs shared by the benificiaries, labour and materials supplied locally. Dilapidated wells were restored. With the availability of water, scarcity of drinking water was mitigated, cultivated land and its productivity increased phenomenally, so also livestock and milk production, household incomes, and employment opportunities, with increased enrollment in schools. Fisheries too provided employment. Marketing facilities followed automatically. Watershed development led to the optimal use of land and water resources, all round growth and economic stability, restoration of ecological balance, and thus significant social and cultural impacts on the community. Water and vegetation being common pool resources, prompted community centered water management based on river basin approach through formation of village councils and River Basin Parliament for conserving water resources, equitable sharing, resolving conflicts. The notion of community ownership of water resource is a means to secure water rights and conserve resource for sustainable use. "Thus Johads became a force to mobilise people, optimise social cohesion, promote self-reliance... and activate community for common good" (Rajendra Singh, Parliament Forum, 2005). UN Report describes Johads as Golden Institution. Former President K.R. Narayanan in 2000 and Prince Charles of Britain in 2003 visited Arwari basin to felicitate the gram sabhas for the spectacular work on water conservation.

Rajendra Singh vigorously launched campaigns like "Ped Bachao Ped Lagao Padayatra", "Aravalli Bachao Yatra", "Jungle Jeevan Bachao Yatra" against illegal mining, and for forest conservation activities and animal husbandry as part of watershed development. Planting trees, constructing johads for animal drinking, setting up people's sanctuary 'Bhairandev Lok-Vinayajeev Abhayarany,' - all these reveal his deep concern for forests and animal life. Increased forests and overall greening led to carbon sequestration, temperature lowering, better rainfall, - a model of climate change mitigation technology.

Alleviation of water miseries freed the women folk from drudgery of fetching water from distances, who could now participate in variety of activities and decision making. Mahila Sangathans, Mahila Banks are testimony of women's emancipation.

A significant achievement of the Project was the revival of the five dry rivers in the Arwari basin, Ruparel, Arvari, Sarsa, Bhagani, Jahajwali to perennial flows through construction of 11,000 water harvesting structures and artificial recharge. In the words of Rajendra Singh: "People should understand the rhythm of water, where water is stagnant allow it to flow, and where it flows allow it to flow slowly and percolate, eliminating evaporation loss. With this realisation groundwater augmentation was possible in Rajasthan through revival of traditional water harvesting systems, using indigenous knowledge and the dying river was rejuvenated (Speech in GSI, Bangalore, April 2007). Replications of this model have followed in other parts of the country too.

The saga of Arwari basin, its message of water security and rehabilitation of dry rivers, the heroic 
efforts of the people of faraway desert of Rajasthan has its resonance across the country and beyond. Rajendra Singh has been deeply moved over the present state of the rivers, - overexploited, encroached upon, and polluted. In 2002, he launched National Water March covering 144 river basins in the northern and southern states of India to create mass awareness to preserve sanctity and purity of rivers. Focussing on "Save River Mission", he has formed Jal Biradari in 11 states in the Ganga Basin. He led a People's march from Gangotri to Gangasagar to appraise the public about the dangers confronting the Ganga, pollution, flow intervention by large dams, ecological degradation. He is opposed to the large hydropower dams in Uttarakhand. He joined the civil Society's Movement in Ganga Cleaning Mission assuming instant leadership role, organising Conclaves, Panchayats, People's march (Pada Yatra) for saving our heritage of rivers. In the wake of the movement Holy Ganga was declared as our National river in 2009. $\mathrm{He}$ is a Member of the National Ganga River Basin Authority. Drawing from his experience of Arwari river regeneration, he has charted out the respective roles of civil society, priests and scientists in the Ganga Cleaning Mission (Rajendra Singh: "Ganga Mandate", 2009), which constitute the protocols of Ganga River Basin Management. Crossing the Vindhyas he has carried the message to the troubled Peninsular rivers for rejuvenation through self-discipline, rainwater harvesting and community water management. 'JanJal Jodo Abhiyan' is his campaign aimed at linking mind and heart of the people to the river. "Development should not tamper with natural flow of the river. Exploitation technology should have in-built soul of the river" (Rajendra Singh, 2007).

This shared objective of water security and conservation has brought Geological Society of India close to Rajendra Singh and TBS culminating in a lasting bond over the past three decades or more. B.P.Radhakrishna (former President of GSI) anointed him in the pages of our Journal as Water Warrior of the day. If TBS is an action agency, motivating and mobilising people at grassroots and implementing the rainwater harvesting and water conservation schemes, GSI is its interface with the society at large,
- scientists, experts, planners, water managers and the public through various workshops/seminars and brainstorming sessions bringing them on a common platform of interactive deliberations, spreading the message of water conservation, equity, sustainability, and harmony of water, man and nature. Notable are the National Seminars held at Bangalore (2007, 2009, 2012, 2013, 2015), Gadag (2008), Bhikampura (2009), Pune (2010). These were all organised in collaboration with TBS and under guidance of Rajendra Singh. The products of these deliberations are in several well documented Memoirs of the Society, which have given a boost to the scientific research. Ichallahalla Watershed in Karnataka is a shining replication of Arwari model undertaken jointly by Krishi Vigyan Kendra (Hulkoti), GSI and TBS. He concurs with the views of the Society on Interlinking of Rivers firmly observing that in nature the rivers don't have any surplus. The solution of the deficit in a basin should be found within the basin itself through self-discipline, water conservation, rainwater harvesting and community management. In 2013 GSI organised a brain storming session at Bangalore jointly with TBS on "River Rejuvenation and River Policy" which aimed at a National Policy for saving the rivers from the destructive overreach of corporates and to ensure equity, sustainability and unhindered pollution-free flow of the rivers. In support of his 'Clean Ganga (Nirmal Aviral Ganga) Mission' GSI promoted studies and several widely acclaimed publications.

The 'green revolution' of the seventies famously succeeded in the water-rich north Indian plains, but not in the rain-deficient plains and plateaus of Peninsular India, and now after nearly three decades is proving unsustainable in many ways. Another 'green revolution', the country was waiting for, has now been ushered in arid Rajasthan through integrated watershed development which takes care of all aspects of rural life, environment and ecosystem in a sustainable manner. Rajendra Singh has revolutionised the concept of watershed development and management integrating water science, climate science, social science, ecological and environmental sciences with ancient knowledge system invoking the Gandhian philosophy of Ram Rajya. Thus emerged the 
realisation that the seed of development is in the villages, and watersheds are key to the National Model of inclusive growth and economic stability. This model is now replicable in the arid and semi-arid areas of India and third world countries. The spectacular contributions of Rajendra Singh in this unique experiment for the well-being of humanity highlight several path breaking concepts.

1. Harmony of science, man and nature.

2. Water security and sustainability through integrated watershed management at watershed level fostering inclusive growth and economic stability.

3. Revival of traditional water harvesting and conservation techniques.

4. Community driven water management and governance. A Revolutionary concept.

5. Arwari watershed and forest management model also provides mitigation technology of global warming and carbon sequestration through greening. An awakening on the eve of climate agreement later this year.

6. River rejuvenation through rainwater harvesting and artificial recharge, as a National Programme.

A colossus among the peers of the day, Rajendra Singh is a legend in his lifetime. He has been recipient of many awards and accolades, both national and international, namely Rotary India Award (1994), Indira Ganghi Paryavaran Purashkar (1994), Raman Magsaysay Award (2001), and Jamanlal Bajaj Award (2005) among others. He is a Member of several Government and UN Committees and delegations. He addressed many national and international forums like Indian Parliament, United Nations, World Bank, Earth Summit, etc, for arousing water conscience of the nations, and presenting the Arwari model of water management and river rejuvenation. He appealed to the nations to think not only of present times but also of future, of sustainable use of water resources. Water is not for profiteering but a gift of nature to be conserved, protected, and equitably shared. UN has since enshrined Arwari river basin as live model of water management through self-help and community empowerment.

I visited the catchments of Tilda, Bhagani and Jahajwali watersheds of Arwari basin in the peak summer of 2009 after consecutive droughts in previous three seasons. The area is hilly with intermontane valleys. Fractured quartzites, schists and gneisses form the aquifers. But the johads or checkdams held stock of water stored in the last rainy season, with lush green fields all around, water in wells, no drinking water scarcity as in ten years back. Farmers were tilling the soil, preparing for cultivation. There was no dearth of soil moisture. Wetlands beckoned cranes. Streams flowing with clear water, aquatic life thriving. Rainwater harvesting has transformed degraded parched lands of Arwari catchment into 'Oasis' in the desert.

He is ever green, though greying a bit with age. Simplicity is his signature, a Gandhian to the core, donning 'kurta and pyjama', a ceaseless traveller through length and breadth of the country carrying and disseminating the message of water wisdom and literacy, rightly described as 'Water Man'. He is fearless, steadfast in conviction, bold in strides, and electrifying in speeches, undeterred by setbacks, $-\mathrm{a}$ charismatic leader always with an infective smile.

Rajendra Singh is the voice of the deprived millions crying for water, food and justice, which if unheeded, may trigger tensions and conflicts, spur many a Arab Spring and Summer, Water Wars. He will be the leading light in the Global Water Peace March, starting from United Kingdom on $14^{\text {th }}$ August 2015. In his words: "This is the century of exploitation, pollution, and encroachment. To stop all this, to convert the war on water into peace, that is my life's goal'. He has gifted the world a dream, a dream of Better Tomorrow, free from water crisis, hunger and poverty.

Rajendra Singh is a Crusader of Water Security, a Messiah of NEW AGE, HOPE and PEACE.

E: subhajyoti_das@hotmail.com SuвналуотіDAS 